locating the course of the temporal branch of the facial nerve during rhytidectomy: an anatomical study". Plastic reconstructive surgery, 116(2), pp. 623-629.

6. Hussein S Abul-Hassan, Grace von Drasek Ascher,Robert D Acland (1986), "Surgical anatomy and blood supply of the fascial layers of the temporal region". Plastic reconstructive surgery, 77(1), pp. 17-28.

7. Harun Cöloglu, Ugur Koçer, Melike Oruç. et al. (2007), "Axial bilobed superficial temporal artery island flap (tulip flap): reconstruction of combined defects of the lateral canthus including the lower and upper eyelids". Plastic reconstructive surgery, 119(7), pp. 2080-2087.

8. Ragip Ozdemir, Nezih Sungur, Omer Sensöz. et al. (2002), "Reconstruction of facial defects with superficial temporal artery island flaps: a donor site with various alternatives". Plastic reconstructive surgery, 109(5), pp. 1528-1535.

\title{
ĐẶC ĐIỂM LÂM SÀNG, HİNH ẢNH SIÊU ÂM CỦA BỆNH NHÂN Có HộI CHỨNG ỐNG CỔ TAY
}

\section{Trần Thị Lan ${ }^{1}$, Lưu Thị Bình ${ }^{1}$, Nguyễn Trường Giang ${ }^{2}$}

\section{TÓM TẮT}

Mục tiêu: Mô tả đăc điểm lâm sàng, hình ảnh siêu âm khớp cổ taycủa các bệnh nhân có hội chứng ống cổ tay điều trị tại bệnh viện Trung ương Thái Nguyên. Đối tượng và phương pháp: Mô tả cắt ngang 36 bênh nhân có 49 ống cổ tay được chẩn đoánxác định hội chứng ống cổ tay theo tiêu chuẩn củaviện quốc gia Hoa Kỳ về sức khỏe và an toàn nghề nghiêp năm1993. Kết quả: Tỷ lệ bệnh nhân nữ/nam=8/1. Tuổi trung bình là $54,4 \pm 12,1$. Triệu chứnglâm sàng của tay bị bệnh: $98 \%$ có tê bì, $87,8 \%$ có đau dọc theo chi phố của dây thần kinh, $75,5 \%$ có di cảm cả ngày lẫn đêm, $79,6 \%$ giảm hoăc mất cảm giác các ngón tay III, IV, V,. Phân độ lâm sàng: 48,9\% ống cổ tay bệnh ở giai đoan trung bình, $32,7 \%$ ở giai đoạn nặng. Tỷ lệ nghiệm pháp Phalen (+) là $87,8 \%$ số ống cổ tay, dấu hiệu Tinel $(+)$ là $63,3 \%$, nghiệm pháp Ducan $(+)$ là $53,1 \%$. Có $57,1 \%$ ống cổ tay có dấu hiệu Notch $(+)$, dấu hiêuu Notch đảo ngược $(+)$ ở $4,1 \%$ ống cổ tay. Dấu hiệu tăng sinh mạch gặp ở $55,1 \%$ ống cổ tay. Diên tích dây thần kinh giữa đâu gần ống cổ tay trung bình $11,1 \pm 1,9$ ở bên tay thuận và $11,7 \pm 1,4$ ở bên không thuận. Kết luận: Triệu chứng lâm sàng thường gặp của hội chứng ống cổ tay là các biểu hiện tổn thương của dây thần kinh giữa. Siêu âm giúp chẩn đoán xác định hội chứng ống cổ tay qua biểu hiện tăng sinh mạch trong dây thần kinh, dấu hiệu Notchs, diện tích dây thần kinh giữa đâuu gần ống cổ tay tăng.

Từ khóa: Hội chứng ống cổ tay, đặc điểm lâm sàng, siêu âm Doppler năng lượng

\section{SUMMARY}

\section{CLINICAL CHARACTERISTICS, IMAGES OF ULTRASOUND OF PATIENTS WITH CARPAL TUNNEL SYNDROME}

\footnotetext{
${ }^{1}$ Trường ĐH Y Dược, Đại học Thái Nguyên

²Bệnh viện Trung Ương Thái Nguyên

Chịu trách nhiệm chính: Lưu Thị Bình

Email: Luuthibinh@tump.edu.vn

Ngày nhận bài: 13/11/2021

Ngày phản biên khoa họ: 14/12/2021

Ngày duyệt bài: 22/12/2021
}

Aim: Description of the clinical characteristics and images of power Doppler ultrasound of patients with carpal tunnel syndrome treated at Thai Nguyen National Hospital. Subjects and methods: Crosssectional description of 36 patients with 49 carpal tunnels diagnosed with carpal tunnel syndrome according to National Institute for Occupational Safety and Health in 1993 from July 2020 to July 2021. Result: Female/male ratio $=8 / 1$. The mean age of the patients was $54,4 \pm 12$. Clinical symptoms of the patients was: $98,0 \%$ of numbness, $87,8 \%$ with pain along the median nerve, $75,5 \%$ of paresthesia during day and night, $79,6 \%$ of decreased or lostsensation in the finger III, IV, V. Phalen test $(+)$ was found in $87,8 \%$ of carpal tunnels, Tinel sign $(+)$ in $63,3 \%$ of the ones, Ducan test $(+)$ in $53,1 \%$ of the ones. There was $57,1 \%$ of the carpal tunnels with Notch sign $(+)$, reversed Notch sign $(+)$ in $4.1 \%$ of the carpal tunnels. Signs of angiogenesis were found in $55,1 \%$ of the carpal tunnel. The median nerve area proximal to the carpal tunnel averaged $11,1 \pm 1,9$ on the preferred hand and $11,7 \pm 1,4$ on the other hand. Conclusion: The most common clinical symptoms of carpal tunnel syndrome were the result of the damaged median nerve. Ultrasound helps to confirm the diagnosis of carpal tunnel syndrome by showing increased angiogenesis in the nerve, Notchs sign, and increased area of the median nerve near the carpal tunnel.

Keywords: Carpal tunnel syndrome, clinical characteristics, power Doppler ultrasound

\section{I. ĐĂT VẤN ĐỀ}

Hội chứng ống cổ tay (Carpal tunnel syndrome) là bệnh lý rất thường gặp, do dây thân kinh giữa trong ống cổ tay khi bị chèn ép và gây ra một loạt các triệu chứng như đau, tê bì, dị cảm, giảm hoặc mất cảm giác gây hạn chế vận động ngón cái, teo cơ ô mô cái[7]. Hội chứng ống cổ tay tuy không gây tử vong nhưng ảnh hưởng lớn đến chất lượng cuộc sông bệnh nhân. Trước đây, chẩn đoán hội chứng ống cổ tay chủ yếu dựa vào lâm sàng. Các test khám thường được ứng dụng trong chẩn đoán bệnh 
gồm: dấu hiệu Tinel, nghiệm pháp Phalen, nghiệm pháp Ducan[7]. Với sự ra đời và phát triển của điện thần kinh cơ và siêu âm, việc ứng dung các phương pháp này đã giúp chẩn đoán hội chứng ống cổ tay ở giai đoạn sớm hơn[6]. Đặc biệt siêu âm là phương pháp chẩn đoán có độ nhạy và độ đặc hiệu cao với chi phí thấp, dễ thực hiện. Tại khoa Cơ xương khớp, bệnh viện Trung ương Thái Nguyên trong thời gian qua đã tiếp nhận điều trị một số lượng bệnh nhân có biểu hiện hội chứng ống cổ tay, tuy nhiên các bệnh nhân thường có biểu hiện bệnh ở giai đoạn muộn, có teo cơ, rối loạn chức năng bàn ngón tay cần phải phẫu thuật. Do đó vấn đề phát hiện chẩn đoán sớm, tìm căn nguyên là rất quan trọng nhằm giúp các bệnh nhân không không phải phẫu thuật trong một số trường hợp hoặc không tiến triển nặng hởn, cũng như tư vẩn phòng bệnh cho các đối tượng có nguy cơ. Vì vậy chúng tôi tiến hành nghiên cứu nàyvới mục tiều sau: Mô tả đặc điểm lâm sàng, hinh ảnh siêu âm khớp cổ tay của các bệnh nhân có hội chứng ông cổ tay điều trị tại bệnh viện Trung ương Thái Nguyên.

\section{II. ĐỐI TƯƠNG VÀ PHƯƠNG PHÁP NGHIÊN CỨU 2.1. Đối tượng nghiên cứu}

- 36 bệnh nhân với 49 cổ tay có hôi chứng ống cổ tay được chẩn đoán xác định hội chứng ông cổ tay theo tiêu chuẩn của viện quốc gia Hoa Kỳ về sức khỏe và an toàn nghề nghiệp (1993) [8]- tất cả các bệnh nhân đã được chẩn đoán xác định hội chứng ống cổ tay dựa vào lâm sàng và kết quả điện thần kinh cơ.

- Bệnh nhân đồng ý tham gia nghiên cứu.

\subsection{Phương pháp nghiên cứu}

2.2.1. Phương pháp nghiên cứu: Nghiên cứu mô tả cắt ngang

- Phương pháp thu thập dữ liệu: tiến cứu từ tháng 7/2020 đến tháng 7/2021.

- Cách chọn mẫu: Chọn mẫu có chủ đích.

- Địa điểm: Khoa cơ xương khớp, phòng khám cơ xương khớp, phòng khám thần kinh, Bệnh viên Trung ương Thái Nguyên.

2.2.2. Nội dung nghiên cứu. Tất cả các bệnh nhân sau khhi được làm điện thần kinh cơ chẩn đoán xác định hội chứng ống cổ tay, được hỏi bệnh, khám lâm sàng, siêu âm theo các chỉ tiêu và biến số nghiên cứu sau:

- Đặc điểm chung:

+ Tuổi: Tính theo năm. Được chia thành 3 nhóm tuổi là <40, 40-60 và >60 tuổi.

+ Giới tính: Nam và nữ.

+ Nghề nghiệp: Lao động chân tay và lao động trí óc.

- Khám lâm sàng:

+ Phát hiện các triệu chứng thần kinh: đau, tê bì, dị cảm chỉ ban đêm, dị cảm cả ngày lẫn đêm, giảm hoặc mất cảm giác theo đường đi của dây thần kinh giữa chi phối.

+ Thực hiện các test lâm sàng: Dấu hiệu Tinel, nghiệm pháp Phalen, nghiệm pháp Ducan trên các cổ tay có xuất hiện triệu chứng tổn thương.

- Dấu hiệu Tinel (+):Gõ trên ông cổ tay ở tư thế duỗi cổ tay tối đa sẽ gây cảm giác đau hay tê giật lên các ngón tay.

- Nghiệm pháp Phalen: Bệnh nhân gập cổ tay hết mức và giữ 60 giây. Nghiệm pháp dương tính nếu bệnh nhân thấy dị cảm vùng dây thần kinh giữa chi phối.

- Nghiệm pháp Ducan: Người khám dùng ngón cái ấn vào vị trí giữa nếp gấp cổ tay bệnh nhân. Nghiệm pháp dương tính khi bệnh nhân thấy tê bì, đau tăng theo vùng phân bố thần kinh giữa [7].

+Phân mức độ trên lâm sàng theo M.Mondelli[9]:

- Mức độ nhẹ: gồm độ 1 + độ 2 (dị cảm ban đêm hoặc dị cảm cả ngày lẫn đêm).

- Mức độ trung bình: độ 3 (giảm cảm giác theo sự chi phối dây thần kinh giữa).

- Mức độ nặng: gồm độ 4 và độ 5 (teo hoặc yếu cơ ô mổ cái một phần hoặc toàn bộ).

- Siêu âm cổ tay: Thực hiện trên các cổ tay có tổn thương tại khoa Chẩn đoán hình ảnh do bác sĩ chẩn đoán hình ảnh và bác sĩ chuyên khoa Cơ xương khớp đọc kết quả.

+ Đặc điểm hình thái dây thần kinh giữa trên siêu âm: dấu hiệu Notch, dấu hiệu Notch đảo ngược, tăng sinh mạch..

- Dấu hiệu Notch: Là dấu hiệu thần kinh giữa bị phù nề như củ hành đoạn sát bờ gần ông cổ tay và dẹt ở đoạn nằm trong ống cổ tay [7].

- Dấu hiệu Notch đảo ngược: Là dấu hiệu thần kinh giữa bị phù nề như củ hành đoạn sát bờ xa ốngcổ tay và dẹt ở đoạn nằm trong ống cổ tay [7].

+ Diện tích dây thần kinh giữa đầu gân ống cổ tay $\left(\mathrm{mm}^{2}\right)$.Chẩn đoán xác định hội chứng ống cổ tay khi diện tích đầu gần dây thần kinh giữa $\geq$ $9,5 \mathrm{~mm}^{2}[3]$.

+ Diện tích dây thần kinh giữa trong ống cổ tay $\left(\mathrm{mm}^{2}\right)$.

+Diện tích dây thần kinh giữa đầu xa ống cổ tay (mm2).

2.3. Xử lý số liệu. Số liệu được thu thập theo mẫu bệnh án nghiên cứu thống nhất. Phẩn tích và xử lý số liệu bằng phần mềm SPSS 18.0 
2.4. Đạo đức trong nghiên cứu. Nghiên cứu đã được Hội đồng $Y$ đức Bệnh viện Trung ương Thái Nguyền thông qua.

\section{KẾT QUẢ NGHIÊN CỨU}

Bảng 1. Đặc điểm chung của đối tượng nghiên cứu

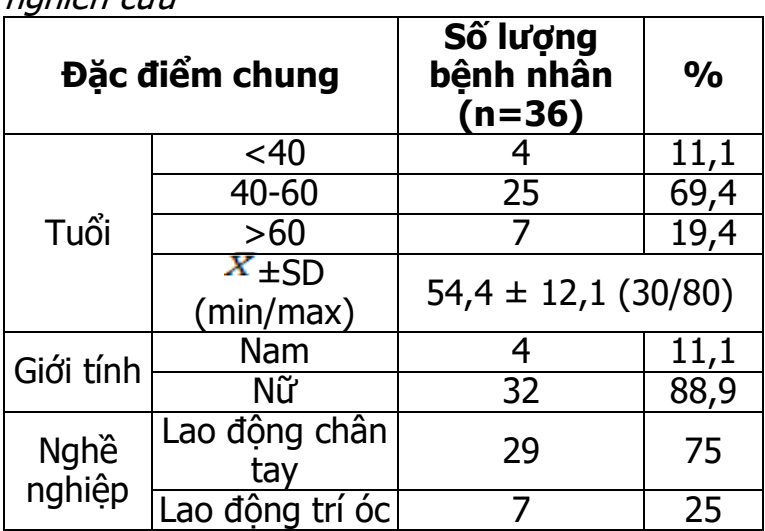

\section{Nhân xét:}

Bểnh gặp chủ yếu ở lứa tuổi trung niên $40-$ 60 chiểm tỳ iệ $69,4 \%$.

Số bệnh nhân nữ chiếm đa số $(88,9 \%)$. Tỷ lệ nữ/ nam là $8 / 1$.
Bệnh chủ yếu gặp ở đối tượng bệnh nhân lao động chân tay (75\%).

Bảng 2. Đặc điểm lâm sàng của hội chứng ông cổ tay các bệnh nhân

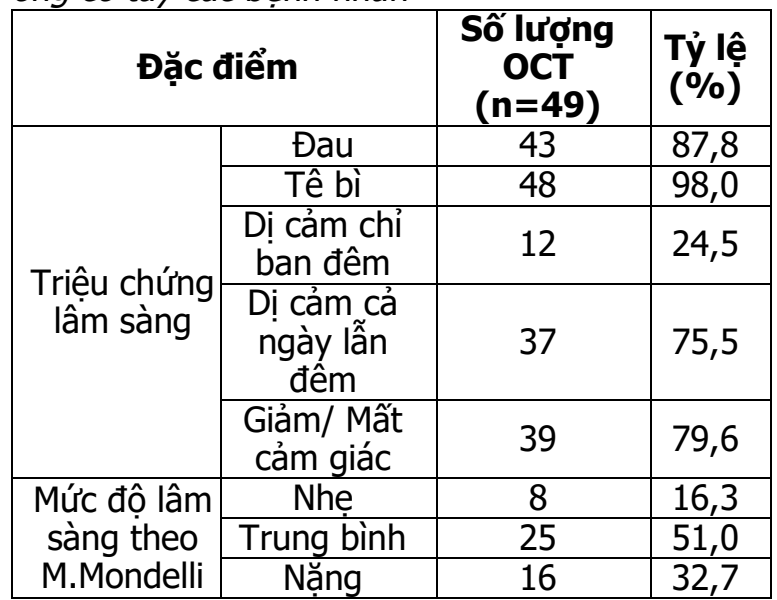

Nhân xét: Triệu chứng hay gặp nhất là tê bì dọc theo đường đi của thân kinh giữa $(98 \%)$, sau đó là triệu chứng đau với tỷ lệ $87,8 \%$. Phần lớn các trường hợp đến viện khi bệnh ở giai đoạn trung bình $(51 \%)$ và nặng $(32,7 \%)$.

Bảng 3. Các test khám lâm sàng cổ tay của đôi tượng nghiên cứu

\begin{tabular}{|c|c|c|c|c|c|c|}
\hline \multirow[b]{2}{*}{ Các test khám } & \multicolumn{2}{|c|}{ Tay thuận } & \multicolumn{2}{|c|}{ Tay không thuận } & \multicolumn{2}{|c|}{ Tổng $(n=49)$} \\
\hline & $\begin{array}{c}\text { Số } \\
\text { lương }\end{array}$ & $\begin{array}{l}\text { Tỷ lệ } \\
(\%)\end{array}$ & $\begin{array}{c}\text { Số } \\
\text { lương }\end{array}$ & $\begin{array}{l}\text { Tỷ lề } \\
(\%)\end{array}$ & Số lượng & Tỷ lệ (\%) \\
\hline Dấu hiệu Tinel (+) & 20 & 55,6 & 11 & 61,1 & 31 & 63,3 \\
\hline Nghiêm pháp Phalen (+) & 29 & 93,5 & 14 & 77,8 & 43 & 87,8 \\
\hline Nghiệm pháp Ducan (+) & 19 & 61,3 & 7 & 38,9 & 26 & 53,1 \\
\hline
\end{tabular}

Nhân xét: Nghiêm pháp Phanlen có độ nhay cao nhất $(87,8 \%)$, tiếp theo là dấu hiêuu Tinel $(63,3 \%)$ và Ducan $(53,1 \%)$. Các nghiệm pháp đều có tỷ lệ dương tính cao hơn ở bên tay thuận.

Bảng 4. Hinh thái dây thần kinh giữa của cổ tay có hội chứng ống cổ tay trên siêu âm

\begin{tabular}{|c|c|c|c|c|c|c|}
\hline \multirow{2}{*}{ Dấu hiệu siêu âm } & \multicolumn{2}{|c|}{ Tay thuận } & \multicolumn{2}{|c|}{ Tay không thuận } & \multicolumn{2}{|c|}{$\begin{array}{c}\text { Tống } \\
(n=49)\end{array}$} \\
\hline & $\begin{array}{c}\text { Số } \\
\text { lượng }\end{array}$ & $\begin{array}{l}\text { Tỷ lệ } \\
(\%)\end{array}$ & $\begin{array}{c}\text { Số } \\
\text { lượng }\end{array}$ & $\begin{array}{l}\text { Tỷ lệ } \\
(\%)\end{array}$ & $\begin{array}{c}\text { Số } \\
\text { lượng }\end{array}$ & $\begin{array}{l}\text { Tỷ lệ } \\
(\%)\end{array}$ \\
\hline $\begin{array}{c}\text { Dây thần kinh giữa phình to ở đầu } \\
\text { gân (Dấu hiêu Notch) }\end{array}$ & 15 & 48,4 & 13 & 72,2 & 28 & 57,1 \\
\hline $\begin{array}{l}\text { Dây thân kinh giữa phình to ở đầu xa } \\
\text { (Dấu hiệu Notch đảo ngước) }\end{array}$ & 1 & 3,2 & 1 & 5,6 & 2 & 4,1 \\
\hline Tằng sinh mạch & 15 & 48,4 & 12 & 66,7 & 27 & 55,1 \\
\hline
\end{tabular}

Nhận xét: Có $57,1 \%$ ống cố tay có dấu hiệu Notch (+). Dấu hiệu tăng sinh mạch gặp ở $55,1 \%$ ống cố tay.

Bảng 5. Diện tích dây thần kinh giữa trên siêu âm

\begin{tabular}{|c|c|c|c|}
\hline Các phép đo & $\begin{array}{c}\text { Tay thuận } \\
(\mathbf{n}=\mathbf{3 1})\end{array}$ & $\begin{array}{c}\text { Tay không thuận } \\
(\mathbf{n = 1 8})\end{array}$ & $\begin{array}{c}\text { Tổng } \\
(\mathbf{n = 4 9})\end{array}$ \\
\hline $\begin{array}{c}\text { Diện tích dây thần kinh giữa đầu gần } \\
\text { ống cổ tay }\left(\mathrm{mm}^{2}\right)\end{array}$ & $11,1 \pm 1,9$ & $11,7 \pm 1,4$ & $11,3 \pm 1,8$ \\
\hline $\begin{array}{c}\text { Diện tích dây thần kinh giữa trong } \\
\text { ống cổ tay }\left(\mathrm{mm}^{2}\right)\end{array}$ & $9,2 \pm 1,4$ & $9,8 \pm 0,8$ & $9,4 \pm 1,2$ \\
\hline $\begin{array}{c}\text { Diện tích dây thần kinh giữa đầu xa } \\
\text { ống cổ tay }\left(\mathrm{mm}^{2}\right)\end{array}$ & $9,4 \pm 2,1$ & $9,8 \pm 1,6$ & $9,6 \pm 1,8$ \\
\hline
\end{tabular}


Nhận xét: Các chỉ số trung bình về diện tích dây thần kinh giữa trên siêu âm của bên tay thuận bị bệnh thấp hơn bên tay không thuận nhưng sự khác biệt không có ý nghĩa thống kê $(p>0,05)$.

Bảng 6. Liên quan giữa diện tích đầu gần thần kinh giữa trênsiêu âm với phân độ nặng trên lâm sàng theo M.Mondelli

\begin{tabular}{|c|c|c|c|c|c|c|}
\hline \multicolumn{2}{|c|}{ Siêu âm } & \multicolumn{5}{|c|}{ Diện tích đâu gân thần kinh giữa CSAb (mm²) } \\
\hline \multirow{2}{*}{\multicolumn{2}{|c|}{ M. Mondelli }} & \multicolumn{2}{|c|}{ Bình thường } & \multicolumn{3}{|c|}{ Bất thường } \\
\hline & & $\mathbf{n}$ & $\%$ & $\mathbf{n}$ & $\%$ & $\mathbf{p}$ \\
\hline \multirow{3}{*}{$\begin{array}{l}\text { Mức } \\
\text { độ }\end{array}$} & Nhe & 0 & 0 & 8 & 100 & 0,526 \\
\hline & Trung bình & 1 & 4,0 & 24 & 96 & 0,281 \\
\hline & Nặng & 3 & 18,8 & 13 & 81,3 & \\
\hline
\end{tabular}

Nhận xét: Tỷ lệ bất thường về diện tích đầu gần dây thần kinh giữa ở người có hội chứng ống cổ tay mức độ nặng theo phân độ M.Mondelli thấp hơn so với những người có mức độ trung bình và nhẹ, nhưng sự khác biệt này không có ý nghĩa thống kê ( $p>0,05)$.

\section{BÀN LUẬN}

4.1. Đặc điểm chung của đối tượng nghiên cứu. Qua nghiên cứu 49 cổ tay có hội chứng ống cổ tay ở 36 bệnh nhân, chúng tổi nhận thây đa phần bệnh nhân là nữ, chiếm tỷ lệ $88,9 \%$. Tuổi trung bình của nhóm bệnh nhân là $54,4 \pm 12,1$. Bệnh gặp chủ yếu ở lứa tuổi trung niên 40-60 (69,4\%) (Bảng 1). Kết quả của chúng tôi cũng tương tự vớinghiên cứu của tác giả Lê Thị Liễu (2018) gặp bệnh nhân có độ tuổi 40-60 tuổi là 74,5\%[3]. Nghiên cứu của tác giả Nguyễn Văn Hướng và cộng sự (2019) gặp tỷ lệ nữ/nam $=14 / 1$ [4]. Các nghiên cứu đều cho rằng phụ nữ dễ bị mắc hội chứng ống cổ tay hơn bởi vì họ hay làm những công việc liên quan nhiều đến vận động ống cổ tay và điều này liên quan mặt thiết đến nghề nghiệp.

Kết quả nghiên cứu của chúng tôi cho thấy nhóm nghề nghiệp sử dụng cổ tay nhiều có tỉ lệ bệnh cao hơn nhóm nghề nghiệp ít sử dụng cổ tay. Trong đó, nhóm lao động chân tay chiếm $75 \%$ trong đó gặp chủ yêu bệnh nhân là làm ruộng, nội trợ,...; lao động trí óc chiếm 25\% (Bảng 1). Kết quả này cũ̃ng phù hợp với nhiều tác giả khác.Trong nghiên cứu dịch tễ về liên quan giữa hội chứng cổ tay và nghề nghiệp ở Anh, tác giả Jenkins PJ và cộng sự (2013) cũng chỉ ra rằng tỉ lệ mới mắc hội chứng ống cổ tay ở những người phải vận động cố tay nhiều như chăm sóc trẻ, thợ cắt tóc, làm thẩm mỹ và y tá nha khoa cao hơn hẳn những người làm công tác nghiên cứu trong phòng thí nghiệm, kỹ sư, luật sư và bác sĩ[5]. Theo Nguyển Văn Hướng và cộng sự (2019) cho thấy nhóm nghề nghiệp sử dụng cổ tay nhiều có tỉ lệ bệnh cao hơn nhóm nghề nghiệp ít sử dụng cổ tay. Trong đó, cao nhất là nhứng người làm ruộng $(33,3 \%)$, nội trợ $(26,7 \%)$, công nhân, giáo viên ít gặp hơn nghể nhân viên văn phòng, kinh doanh (3\% đến $5 \%$ ) [4].

4.2. Đặc điểm lâm sàng. Về đặc điểm lâm sàng hội chứng ống cổ tay của các đối tượng nghiên cứu của chúng tôi thấy nổi bật làtriêuu chứng tê bì bàn tay chủ yếu là ngón cái, ngón trỏ, ngón giữa và nửa ngón nhẫn với tỷ lệ $98,0 \%$ ống cổ tay bệnh; $87,8 \% \%$ biểu hiện đau, bệnh nhân thường có cảm giác đau buốt nhói như kim châm hoăc đau rát bỏng; 75,5 biểu hiện tê bì ở da bàn tay cả ngày lẫn đêm xảy ra theo khu vực chi phối của dây thần kinh giữa, người bệnh thường hay mô tả cảm giác lâm râm như kiến bò ngoài da (Bảng 2. Kết quả nghiên cứu của chúng tôi cũng tương đồng với kết quả của các tác giả khác. Theo Lê Thị Liễu, triệu chứng tê và dị cảm chiếm 96\%, đau 35,1\%[3]. Đỗ Lập Hiếu gặp tỷ lệ có tê, dị cảm, đau ở bàn tay là $80 \%$ [1]. Trong nghiên cứu về hội chứng ống cổ tay vô căn ở Nhât củatác giả Iida, triệu chứng tê dị cảm chiếm $96 \%$, đau bàn tay chiếm $71 \%$ [6]. Bệnh nhân có triệu chứng giảm hoặc mất cảm giác trong nghiên cứu của chúng tôi cao hơn rõ so với các nghiên cứu khác[3], [1]. Có sự khác biệt này có thể do phần lớn bệnh nhân của chúng tổi đến viện khi bệnh đã ở giai đoạn muộn. Cụ thể: $51,0 \%$ ống cổ tay mức độ trung bình, $32,7 \%$ mức độ nặng, mức độ nhẹ chỉ chiếm 18,3\% (Bảng 2).

Nguyên nhân rối loạn cảm giác hay gặp và xuất hiện sớm hơn trong hội chứng ống cổ tay là do các sợi dẫn truyền cảm giác là những sợi thần kinh có myelin, kích thước lớn nên dễ bị tổn thương hơn các sợi vận động. Yếu cơ và teo cơ ô mô cái ít gặp hơn và thường xảy ra ở giai đoạn muộn do tổn thương các sợi thần kinh vận động và thoái hóa sợi trục thần kinh [7].

Kết quả nghiên cứu của chúng tôi cho tỷ lệ nghiệm pháp Phalen dương tính là 87,8\% (Bảng 3), cao hơn các nghiên cứu của tác giả Lê Thị Liễu $(63,6 \%)$, Đỗ Lập Hiếu (70\%)[3], [1]. Sự khác biệt này có thể do tỷ lệ bệnh nhân của chúng tổi được chẩn đoán ở giai đoạn nặng có tỷ lệ cao hơn. Mặc dù tỷ lệ có khác nhau nhưng các tác giả đều cho rằng đây là một trong các 
nghiệm pháp lâm sàng có giá trị cao trong chẩn đoán hội chứng ống cổ tay.

Dấu hiệu Tinel trong nghiên cứu của chúng tôi có tỷ lệ dương tính thấp hơn nghiệm pháp Phalen nhưng cao hơn nghiệm pháp Ducan. Tỷ lệ test Tinel dương tính trong nghiên cứu củachúng tôi là 63,3\% (Bảng 3), tương tự như nghiên cứu của Lê Thị Liễu $(67,9 \%)$ [3]. Cùng với nghiệm pháp Phalen, đây là một trong những nghiệm pháp lâm sàng kinh điển có giá trị tương đối cao trong chẩn đoán lâm sàng hội chứng ống cổ tay.

Nghiệm pháp Ducan được áp dung nhiều trong lâm sàng chẩn đoán hội chứng ống cổ tay. Theo Lê Thị Liễu, nghiệm pháp Ducan có độ nhạy là 52,6\%[3], tương đương với kết quả trong nghiên cứu của chúng tôi với tỷ lệ dương tính của nghiệm pháp này là $53,1 \%$. (Bảng 3 ) Mặc dù đây là nghiệm pháp lâm sàng ra đời sau hai nghiệm pháp Tinel và Phalen nhưng giá trị chẩn đoán của nó cũng khá cao, chính vì vậy mà cũng được ứng dụng rộng rãi trong thực hành cùng với hai nghiệm pháp trên.

4.3. Đặc điểm siêu âm khớp cổ tay của đối tượng nghiên cứu. Qua thực hiện siêu âm các ống cổ tay của bệnh nhân cho kết quả: $57,1 \%$ có dấu hiệu Notch, $4,1 \%$ có dấu hiệu Notch đảo ngược, $55,1 \%$ có dấu hiệu tăng tưới máu (Bảng 4). Nghiên cứu của tác giả Đoàn Viết Trình (2015) có tỷ lệ cao hơn với dấu hiệu Notch (+) $73 \%$, dấu hiệu Notch đảo ngược (+) 16\%, $35,1 \%$ tăng tưới máu thần kinh giữa [2].

Sư khác biêt này có thể do nghiên cứu của Đoàn Viết Trình đối tượng bệnh nhân đều có chỉ định phẫu thuật tức là ở giai đoạn bệnh trung bình đến nặng. Vì vậy dấu hiệu Noch đảo ngược trong nghiển cứu của Đoàn Viết Trình cao hớn trong nghiên cứu của chúng tôi.

Chúng tôi đã đo diện tích thần kinh dựa vào vẽ chu vi mặt cắt ngang qua thần kinh, không đo theo kích thước hai chiều (chiều ngang và chiều trước sau). Việc đo theo chu vi có tính chính xác hơn, ít phụ thuộc vào tư thế bệnh nhân và mức độ đè ép của người siêu âm. Diện tích cắt ngang thần kinh giữa được đo 3 vị trí: đoạn sát bờ gần ống cổ tay là $11,3 \pm 1,8$; trong ống cổ tay là $9,4 \pm 1,2$; bờ xa ống cồ tay là $9,6 \pm 1,8$ (Bảng 5 ). Kết quả diện tích cắt ngang dây thần kinh giữa trung bình ở đầu gần ống cổ tay trong nghiên cứu của chúng tôi thấp hơn của Lê Thị Liễu (2018): 13,3 4 4,6 mm², Đoàn Viết Trình (2015): $17,3 \pm 7,2 \mathrm{~mm} 2[2],[3]$.

Khi diện tích thân kinh tăng và phù nề giảm âm chứng tỏ dây thần kinh bị chèn ép cấp. Khi khảo sát mối liên quan giữa diện tích đầu gần thần kinh giữa với phân độ nặng trên lâm sàng theo M.Mondelli chúng tôi nhận thấy rằng: Tỷ lệ bất thường về diện tích đầu gần dây thần kinh giữa ở người có hội chứng ống cổ tay mức độ nặng theo phân độ M.Mondelli thấp hơn so với những người có mức độ trung bình và nhẹ, nhưng sự khác biệt này không có ý nghĩa thống kê $(p>0,05)$. Theo Lê Thị Liễu (2018), có sự khác biệt có nghĩa thống kê về diện tích cắt ngang dây thần kinh giữa ở cả 3 nhóm, nhẹ , trung bình, nặng theo phân độ lâm sàng M.Mondelli với $r=0,5, p<0,01$ [3]. Điều đó có nghĩa là nếu phân độ lâm sàng theo M.Mondelli càng nặng thì diện tích cắt ngang dây thần kinh giữa càng lớn. Có sự khác biệt này có thể do do phần lớn các bệnh nhân trong nghiên cứu của chúng tôi đến viện khi bệnh đã ở mức độ nặng và trung bình- khi dây thần kinh giữa qua giai đoạn phù nề.

\section{KẾT LUÂN}

- Bệnh nhân có tỷ lệ nữ/nam $=8 / 1$. Tuổi trung bình là $54,4 \pm 12,1$, trong đó $69,4 \%$ bệnh nhân ở độ tuổi 40-60.

- 75\% bệnh nhân thuộc đối tượng lao động chân tay.

- Triệu chứng lâm sàng nổi bật của tay bị hội chứng ổng cổ tay: $98 \%$ có tê bì; $87,8 \%$ có biểu hiện đau; $79,6 \%$ giảm hoặc mất cám giác dọc theo chi phối thần kinh giữa.

- Nghiệm pháp Phanlen (+) cao nhất $(87,8 \%)$, dấu hiệu Tinel $(+)$ là $63,3 \%$ và Ducan (+) là $53,1 \%$.

- 51\% ống cổ tay bệnh ở giai đoạn trung bình, $32,7 \%$ ở giai đoạn nặng theo phân độ M.Mondelli.

- Trên siêu âm cổ tay có hội chứng ống cổ tay: $57,1 \%$ có dấu hiệu Notch $(+), 55,1 \%$ có dấu hiệu tăng sinh mạch. Diện tích dây thân kinh giữa đầu gân ống cổ tay trung bình đoạn sát bờ gần ống cổ tay là $11,3 \pm 1,8$; trong ống cổ tay là $9,4 \pm 1,2 ;$ bờ xa ống cổ tay là $9,6 \pm 1$.

- Tỷ lệ bất thường về diện tích đầu gần dây thần kinh giữa ở người có hội chứng ống cổ tay mức độ nặng theo phân độ M.Mondelli thấp hơn so với những người có mức độ trung bình và nhẹ, nhưng sự khác biệt này không có ý nghĩa thổng kê.

\section{TÀI LIÊU THAM KHẢO}

1. Đỗ Lập Hiếu (2014), "Nhận xét lâm sàng và các bất thường trên điên sinh lý thần kin hở bênh nhân mắc hội chứng ống cổ tay", Tạp chí Y - dược học quân sứ. 8,pp.136-140.

2. Đoàn Viết Trình, Bùi Văn Lệnh (2015), "Đặc 
điểm hình ảnh và vai trò̀ của siêu âm trong chẩn đoán và theo dõi sau phẫu thuật hội chứng ống cổ tay", Nghiên cứu khoa hoc. 20,pp.12-17.

3. Lê Thị Liểu (2018), Nighiên cứu đặc điểm lâm sàng, điện cơ và siêu âm doppler năng lượng trong hội chứng ống cổ tay, Đại học Y Hà Nội.

4. Nguyển Văn Hướng, Lể Thị Trạng (2019), "Đánh giá một số yếu tố liên quan đến hội chứng ống cổ tay trên bệnh nhân người trưởng thành", Tap chí nghiên cứu y học. 117 (1),pp.77-83.

5. Jenkins P. J., Srikantharajah D., Duckworth A. D., et al. (2013), "Carpal tunnel syndrome: the association with occupation at a population level", J Hand Surg Eur Vol. 38 (1),pp.67-72.

6. Iida 'J., Hirabayashi H., Nakase H., et al.
(2008), "Carpal tunnel syndrome: electrophysiological grading and surgical results by minimum incision open carpal tunnel release", Neurol Med Chir (Tokyo). 48 (12),pp.554-559.

7. Padua L., Coraci D., Erra C., et al. (2016), "Carpal tunnel syndrome: clinical features, diagnosis, and management", Lancet Neurol. 15 (12),pp.1273-1284.

8. "Practice parameter for electrodiagnostic studies in carpal tunnel syndrome: summary statement. American Association of Electrodiagnostic Medicine, American Academy of Neurology, American Academy of Physical Medicine and Rehabilitation", (1993), Muscle Nerve. 16 (12),pp.1390-1391.

\section{KHẢO SÁT ĐẶC ĐIỂM LÂM SÀNG THEO Y HỌC CỔ TRUYỀ CỦA BÊ̂NH NHÂN TRĨ SỬ DỰG MÔ HÌNH CÂY Tİ̂̀M ẨN.}

\section{TÓM TẮT}

Mục tiêu: Khảo sát triệu chứng lâm sàng và thể bênh y hoc cổ truyền (YHCT) của người bênh trĩ. Đối tượng và phương pháp: 965 bệnh nhẩn trĩ được chẩn đoán và điều trị tại khoa ngoại Bệnh viện y học cổ truyền Trung Ương. Mô hình cây tiềm ẩn được sử dụng và thiết lập để phân tích dữ liệu về hội chứngYHCT từ các bệnh nhân trĩ. Kết quả: Đã xây dựng được mô hình cây tiềm ẩn với điểm tiêu chí thông tin Bayes cao nhất.Mô hình này cho thấy đặc điểm của các hôi chứng YHCTcơ bản ở bệnh nhân trĩ gồm 42 triệu chứng với 4 thể bệnh bao gồm: phong thương trường kết, thấp nhiệt hạ chú, tỳ hư hạ hãm, khí trệ huyết ứ. Kết luận: Sử dụngmô hình cầy tiềm ẩn giúp phân chia nhóm các triệu chứng lâm sàng vàphân loại các hội chứng YHCT của bệnh trĩ.

Tư khóa: Bệnh trĩ, mô hình cây tiềm ẩn.

\section{SUMMARY}

SURVEY CLINICALSYMPTOMS TRADITIONAL MEDICINE OF HEMORRHOIDS USING LATENT TREE MODEL ANALYSIS

Objectives: To investigate the clinical symptoms of traditional medicine diseases inhemorrhoid patients. Subjects and methods: 965 patients with hemorrhoids in Vietnam's traditional medicine hospital. The latent tree model was used to analyze traditional medical syndrome data from patients with hemorrhoids. Results: The latent tree model was established with the highest Bayes information criterion. This model revealed 42 symptomatic and 4

\footnotetext{
${ }^{1}$ Bệnh viện Y học cổ truyền $T U$,

${ }^{2}$ Học viền Y Dược hoc cổ truyền $V N$

Chịu trách nhiệm chính: Lê Mạnh Cường

Email: drcuong68@gmail.com

Ngày nhận bài: 14/11/2021

Ngày phản biên khoa họ: $7 / 12 / 2021$

Ngày duyệt bài: 23/12/2021
}

\section{Lê Mạnh Cường', Ngô Thị Khuyên ${ }^{2}$}

syndromes in hemorrhoid patients.include:wind injuring intestine collaterals, damp-heat pouring downward, spleen qi deficiency, qi stagnation and blood stasis. Conclusion: The latent tree was effective in classifying clinical symptoms and the traditional medical syndromes of hemorrhoids.

Keywords: Hemorrhoids, the latent tree model.

\section{I. ĐĂT VẤN ĐỀ}

Trĩ là bệnh lý của đám rối tĩnh mạch vùng hâuu môn trực tràng, do nhiều nguyên nhân làm cho hệ thống tĩnh mạch này sa giãn không hồi phục [1]. Bệnh này chiếm $87,25 \%$ các bênh về hậu môn trực tràng [2]. Y học cổ truyền (YHCT) đã mô tả về bệnh trĩ trong các y văn, tuy nhiên việc mô tả nguyên nhân, các đặc điểm lâm sàng và phân thể bệnh chưa thống nhất. Cho đến nay vẫn còn thiếu các tiêu chí khách quan để phân biệt các hội chứng YHCT của bệnh. Mô hình cây tiềm ẩn là mô hình đồ họa theo xác suất với cấu trúc là mạng Bayes dạng cây, trong đó các nút lá đại diện cho các biến biểu hiện được quan sát và các nút nội bộ đại diện cho các biến tiềm ẩn [3]. Phân tích cây tiềm ẩn là một phương pháp phân tích cum dưa trên mô hình phân lớp ẩn. Mô hình cây tiềm ẩn cung cấp một phương pháp thống kê khoa học để phân loại các hội chứng YHCT và cho thây khả năng thành lập tiêu chuẩn chẩn đoán khách quan và định lượng để phân biệt các hội chứng [4]. Vì vậy, trong nghiên cứu này chúng tôi tiến hành xây dựng tiêu chuẩn chẩn đoán vàkhảo sát triệu chứng lâm sàng và thể bệnh YHCT của bệnh nhân trĩ sử dụng mô hình cầy tiềm ẩn.

II. ĐỐI TƯỢNG VÀ PHƯƠNG PHÁP NGHIÊN CỨU

2.1. Đối tượng nghiên cứu: 965 bệnh 